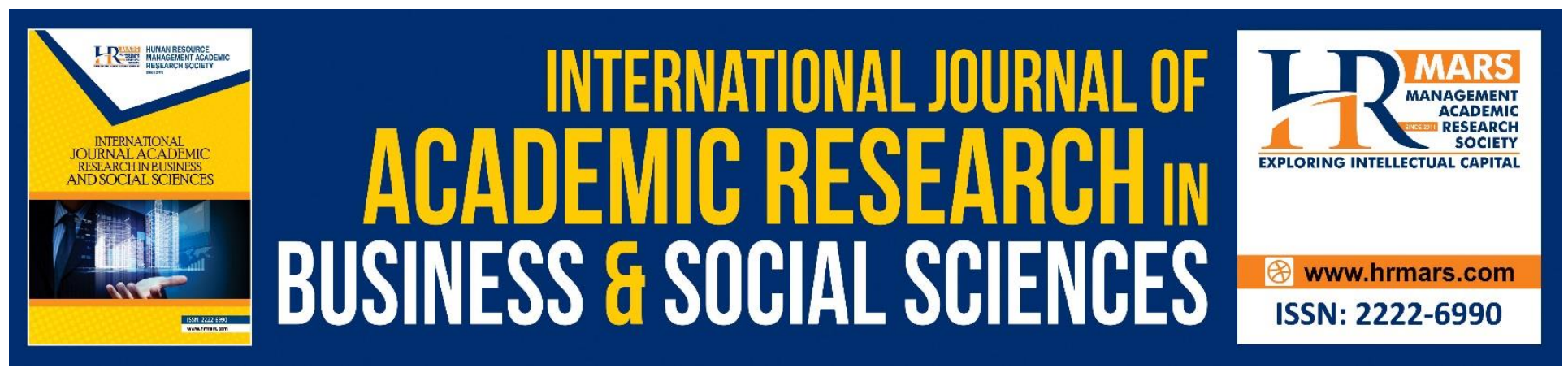

\title{
The Revival of Mudharabah Contract: Proposed Innovative Solutions
}

Siti Nurzahira Che Tahrim, Mohd Syakir Mohd Rosdi, Mohd Zulkifli Muhammad, Mohd Nor Hakimin Yusoff, Azizah Musa, Noormariana Mohd Din

To Link this Article: http://dx.doi.org/10.6007/IJARBSS/v8-i10/4723 DOI: $10.6007 /$ IJARBSS/v8-i10/4723

Received: 19 Sept 2018, Revised: 26 Oct 2018, Accepted: 27 Oct 2018

Published Online: 30 October 2018

In-Text Citation: (Tahrim et al., 2018)

To Cite this Article: Tahrim, S. N. C., Rosdi, M. S. M., Muhammad, M. Z., Yusoff, M. N. H., Musa, A., \& Din, N. M. (2018). The Revival of Mudharabah Contract: Proposed Innovative Solutions. International Journal of Academic Research in Business and Social Sciences, 8(10), 174-190.

Copyright: (C) 2018 The Author(s)

Published by Human Resource Management Academic Research Society (www.hrmars.com)

This article is published under the Creative Commons Attribution (CC BY 4.0) license. Anyone may reproduce, distribute, translate and create derivative works of this article (for both commercial and non-commercial purposes), subject to full attribution to the original publication and authors. The full terms of this license may be seen

at: http://creativecommons.org/licences/by/4.0/legalcode

Vol. 8, No. 10, 2018, Pg. 174 - 190

http://hrmars.com/index.php/pages/detail/IJARBSS

JOURNAL HOMEPAGE

Full Terms \& Conditions of access and use can be found at http://hrmars.com/index.php/pages/detail/publication-ethics 


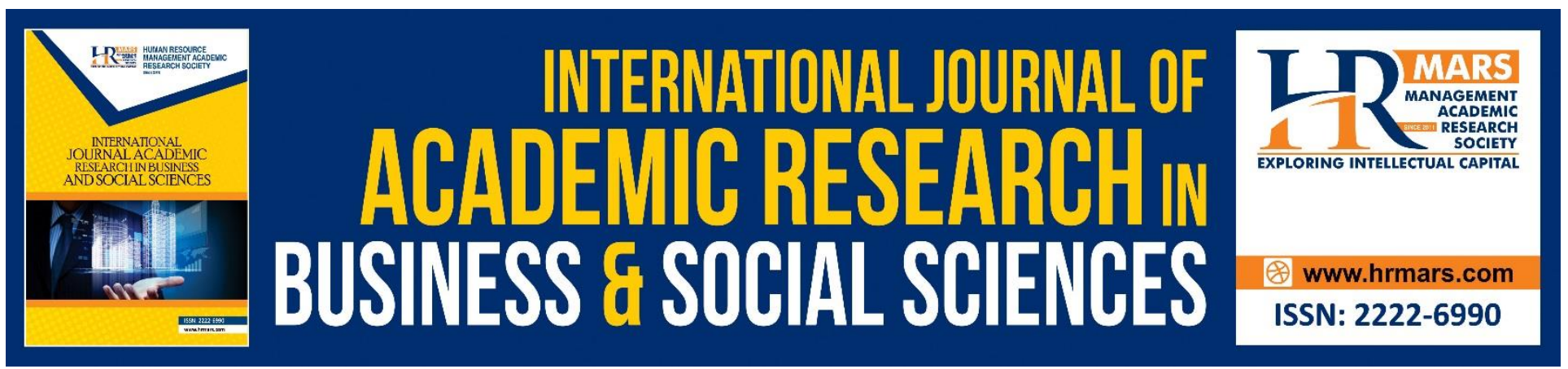

\title{
The Revival of Mudharabah Contract: Proposed Innovative Solutions
}

\author{
Siti Nurzahira Che Tahrim ${ }^{1}$, Mohd Syakir Mohd Rosdi ${ }^{*}$, Mohd Zulkifli \\ Muhammad $^{3}$, Mohd Nor Hakimin Yusoff ${ }^{4}$, Azizah Musa ${ }^{5}$, \\ Noormariana Mohd $\mathrm{Din}^{6}$ \\ 1,3,4,5,6 Faculty of Entrepreneurship \& Business, Universiti Malaysia Kelantan \\ $2^{2}$ Centre for Islamic Development Management Studies (ISDEV), Universiti Sains Malaysia \\ Email: 1nurzahira@umk.edu.my,2*mohdsyakirmohdrosdi@gmail.com, 33ulkifli.m@umk.edu.my, \\ ${ }^{4}$ hakimin@umk.edu.my, ${ }^{5}$ mariana.md@umk.edu.my, ${ }^{6}$ azizah.m@umk.edu.my
}

\begin{abstract}
The repulsion of mudharabah (Islamic profit sharing) concept surfaces more obviously than before particularly in the banking sector. As a consequence, the product become less attractive and could be scrapped off from the banking services which eventually give negative image to the Islamic principles claimed as the way of life. While the banking sector may not be a fertile soil for mudharabah to bloom, a real business relationship context between investors and entrepreneurs is believed to be the future home for pure (non-engineered) mudharabah to recognise its real benefits. We believe that to realise the mudharabah's true potentials, among others, the contract needs to be revived. The purpose of this study is to propose solutions in reviving the mudharabah contract between the sahibul mal (investor) and the mudharib (entrepreneur). The research methods used in this study were content analysis of the current contract guideline and in-depth interview of five different stakeholders; investor, entrepreneur, Shariah advisor, academician and lawyer. As a result, the new framework, clauses and format were recommended to revive the mudharabah contract to include procedures to prevent anticipated problems and to preserve the agreement based on Shariah as well as to encourage venturing into high profitability potential business. This proposed solution could serve as an innovative and comprehensive template for future mudharabah contract that seem to be more understandable, implementable and has substance over form. The revived contract template may also be used to convince the interested parties to have more faith on pure mudharabah benefits.
\end{abstract}

Keywords: Mudharabah, Contract, Akad, Framework, Revive 


\section{Introduction}

Sustainable Business Model (SBM) uses sustainabilitiy concept to drive force of the firm and become a main consideration in making decision. It focuses on economic, environmental and social outcomes (Stubbs \& Cocklin, 2008).There are many decisions a business should make in maintaining sustainability and balancing the triple bottom lines (economic, environmental and social outcomes). The decisions also include investment and financing choices.

As part of a holistic ecosystem, entrepreneurial ecosystem is vital to ensure its business sustainability contributions. Financing and investment which involves risks and market disciplines will give direct and indirect impacts to the ecosystem and the sustainability's triple bottom lines. In particular, Mudharabah; as an Islamic profit-sharing contract between investor (capital provider) and entrepreneur (businessman) is a robust principle to support the sustainable ecosystem.

\section{Background}

Ecosystems can be defined as life-support systems, providers of ecosystem services and economic benefits (Ehrlich \& Mooney, 1983; Odum, 1989; Folke et al., 1991; De Groot, 1992). Ecosystem and human wellbeing are interrelated and can be described by natural capital and ecosystems services. While natural capital is "an economic metaphor for the limited stocks of physical and biological resources found on earth", the ecosystem services provide supports to facilitate the transition from ecosystem processes and components to their goods and services (De Groot et al., 2002). The Millennium Ecosystem Assessment (2005) categorized four components in ecosystem services; supporting, provisioning, regulating and cultural. As natural capital is limited, the wrong mix and actions will lead to biodiversity loss and deprivation of ecosystem (de Groot, Fisher, \& Christie, 2010).

As part of the whole ecosystem, entrepreneurial ecosystem is a component within it. According to Babson Global, entrepreneurial ecosystem consists of six domains; Policy, Finance, Culture, Supports, Human Capital, and Markets. For the ecosystem to work, integration of relevant parties is critical. Universities are taking part actively in contributing in the entrepreneurial ecosystem by supplying potential entrepreneurs to the economy. For example, Universiti Malaysia Kelantan (UMK); an entrepreneurial university, is assigned to particularly achieve the mission. In doing so, many entrepreneurial programmes are developed to build and enhance particularly the human capital domain of the entrepreneurship ecosystem.

In terms of financial, current entrepreneurial ecosystem is supported by financing resources provided by government such as TEKUN, subsidised private micro financing (Amanah Ikhtiar Malaysia - AIM) and other micro credit facilities offered by banks. Issues arise from the current setting include nonperforming loans in TEKUN, high interests charged by AIM and tight selection criteria by banks.

Muslim entrepreneur's business practices are influenced by the Islamic faith that stresses on caring for society and environment (Maqasid Shariah) through entrepreneurs activities (Faizal, Ridhwan, \& Kalsom, 2013). The Muslim entrepreneurs' activities are elaborated in the issue of human capital quality and ethics (Ahcene, 2013). As such, under Islamic perspective, the promotion of Mudharabah 
venture capital model is an instance. This model is suitable for the entrepreneurship activities as it represents the contributions to the social economic redistribution goals in the economy and prohibition of Shariah non-compliant activities such as interest on loan. Such prohibition protects the human beings and the ecosystem. In order to improve the ecosystems' natural capital, it recognizes any incentives and institutions that will guide the investment and business activities (Gretchen, 2008). The stability of financial domain in entrepreneurial ecosystems generally depends on the investor's decision. An appreciation of valuable capital assets in Islamic financing such as Mudharabah, strengthen the foundations of the Islamic finance (BNM, 2010).

Therefore, we aim to support the local entrepreneurship ecosystem by introducing pure mudharabah model; an Islamic profit-sharing relationship which is deemed to be one of the best solutions in investing and raising capital for budding entrepreneurs. This muamalat model which consists of social and spiritual values will in turn solve the imbalanced entrepreneurial ecosystem holistically.

\section{Problem Statement}

For investors, there are many financial assets choices such as stock and shares, bonds, sukuk, private or government securities and many more. However, such investments are unprotected from speculative activities and potential bubble bursts. The bubble bursts due to sharp appreciation of values higher than fundamentals (no real economic activities), followed by market crash (Diaz, 2016). There are some investors who prefer higher risks investments such as direct investments. However, current available investment vehicles provide returns in terms of growth (capital gains) or income (dividends payout), but no real profit-sharing from the invested business.

From entrepreneurs' viewpoint, they are in dilemma between implementing their innovative business ideas and facing the difficulties in raising capital. Most capital financing charge high rates which put pressure on the entrepreneurs (Koveos \& Randhawa, 2005). A business may collapse, not because of underperforming, but due to the inability to meet the demanding financing costs, particularly at the business' early stage or when facing adverse economic climate. Entrepreneur, who initially does business to raise his/her own social and economic standards, may find him/herself trapped in a deeper financial crises due to this unflexible capital financing problem.

The financial domain in entrepreneurship ecosystem is provided by private or government-linked institutions and banks that extend financial assistance to the entrepreneurs. The current embedded financial capitalism which focuses on wealth and consumption maximization creates imbalanced state and self-destructive ecosystem. In contrast, values in Islamic economy urge moderation in material quests and thoughtful when making private decisions on public good, in addition to pragmatism (Kingabdulaziz, 2009). There are also philanthropies whose intention is to help the poor (Siddiqi, 2008), or angel investors who would risk their own money and benefit some returns while helping others, through investing in entrepreneur's income generating activities (Sanyal \& Mann, 2010). Unfortunately, there are some issues surrounding this situation, whereby not all poor who received the capital are interested in entrepreneurship (Aliber, Kirsten, Maharajh, Nhlapo-Hlope, \& Nkoane, 2006). In addition, some capital receivers are too poor that they want to only utilise those 
capital raised for consumption rather than business activities (Fairbourne, Gibson, \& Dyer, 2007). The microfinance institutions are also often charging very high rates (Chhay, 2011) which burdening the budding entrepreneurs.

On another notes, an Islamic profit-sharing; mudharabah, is a contract between investor and entrepreneur. In mudharabah, the profit accumulated resulting from business activities must be shared on the predetermined contractual ratio and only the investor bears all economic losses so long the entrepreneur is doing the business uprightly (Kwon, 2007). This is a very fair model as the entrepreneurs are not strained, yet place reasonable sense of responsibility to make profit and share it with the investor. The entrepreneur also cannot use the capital for consumption as the investor is following the business performance after the disbursement of capital. Mudharabah could be one of the best solutions which cover at least financial, support and human capital domains. Since mudharabah is thus far only contracted as part of financial engineered products and fairly known by the investors and entrepreneurs, it is timely that its true potential should be tapped through direct mudharabah contract implementation via improvements on pure Mudharabah contract which should solve the agency problem and enhance relationship between the (angel) investors and the entrepreneurs.

Furthermore, most importantly there is a blessing in implementing mudharabah. This is as mentioned in a hadith:

"Suhaib r.a. said that the Prophet said: "There are three things to be a blessing. Buying and selling which is not in cash, Muqaradhah (mudharabah), and mixing wheat with barley for domestic purposes, not for sale" (Narrated by Ibn Majah, Hadith No.: 2289).

However, mudharabah is sidelined due high risk resulting from process and contract implementation deficiencies. This deficient setting is therefore, open to fraud and deliberate non-performance of entrepreneur.

Hence, this study aims to strengthen the Mudharabah contracts in order to sustain the investorentrepreneur profit-sharing implementation by studying the requirements of the Shariah principles and expectations by both investor and entrepreneur.

\section{Research Objectives}

The objective of this paper is to propose solutions in reviving the mudharabah contract between the sahibul mal (investor) and the mudharib (entrepreneur) in a pure investor-entrepreneur relationship context. This proposed framework, clauses and format of the contract will be used in developing an improved Mudharabah contract template for future use.

\section{Research Methodology}

In order to achieve the objectives outlined above, we used qualitative method; content analysis on mudharabah current guideline and in-depth interview of five different stakeholders; investor, entrepreneur, Shariah advisor, academician and lawyer. 
This study is conducted based on these assumptions:

a) The investors to have positive attitudes to offer Pure Mudharabah if fair, clear and flexible Mudharabah contracts are in place.

b) The entrepreneurs to have positive attitudes towards delivering responsibilities in Pure Mudharabah if fair, clear and flexible Mudharabah contracts are in place.

c) Pure Mudharabah is operationalisable when parties involved in the legally binding Mudharabah contracts have positive attitudes towards assuring the fair, clear and flexible terms and conditions of the contract.

The proposed contract can be utilised by any interested individuals or corporations in investing in direct ventures, who wish to realise the true potential of Mudharabah, while protecting interests of the parties involved.

\section{Findings: Concept Of Mudharabah}

Mudharabah is a contract between sahibul mal and mudharib with predetermined contract terms agreed, such as the profit-sharing ratios and the period of the contract. In mudharabah, the sahibul mal provides $100 \%$ capital, while the mudharib contirbutes $100 \%$ time, ideas and energy in running the business. When the business profits, the sahibul mal and the mudharib will share the profits for example based on ratio of 60:40, 30:70, 20:80 and so on. In case of business loss due to adverse economic climate, the sahibul mal will bear the loss fully, while the mudharib lost his time and energy. However, if the business makes loss due to mudharib's negligence, the mudharib will bear the loss.

At the end of the contract period, the mudharib will return the capital provided by the sahibul mal. This is a type of mudharabah contract called Mudharabah Muqayyadah, which means mudharabah with conditions. Other than specific time period, conditions that the sahibul mal may dictate is the type of business that the mudharib may involve in. The basic model of mudharabah can be presented as shown in Figure 1.

Another type of mudharabah is Mudharabah Mutlaqah. In this contract, the sahibul mal will let the mudharib does what he/she thinks best for the business and the capital to grow, as long as it is not against the Shariah. If there is no specific time period, the capital provided need not be returned and the profits must be shared as per agreed profit-sharing ratio. This type of mudharabah is suitable for sahibul mal and mudharib who have good long-term relationship and highly trust each other. Either party can end the contract when deemed necessary and it must be agreed by the other party. 


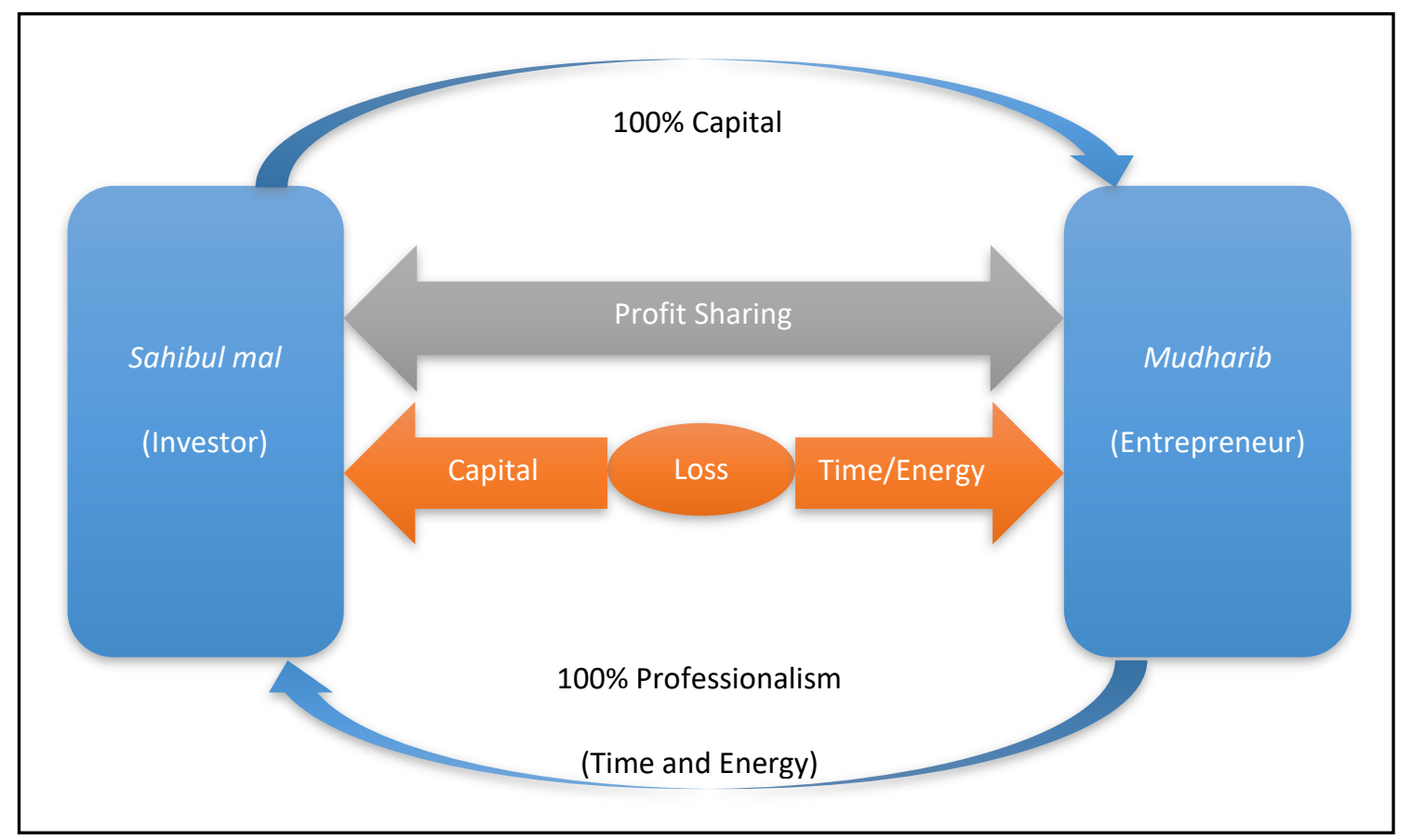

Figure 1. The Mudharabah Model

In general, mudharabah has three fundamental elements which contributes to the accomplishment of its contract agreement. First, guarantee; second, fairness and third, benefits. These three elements seem to be perfect from the Islamic mujtahid's view point who promoted the implementation of mudharabah.

Mudharabah must also be implemented with specific pillars and conditions. The pillars of mudharabah, as explained by Imam An-Nawawi (2007) are five. First, capital; second, types of business; third, profit; fourth, sighah (the agreement in accepting the terms of the contract); and fifth, two parties involved in the contract; who are the sahibul mal and the mudharib.

Four conditions of the pillars in mudharabah ruled are conditions of agreement, conditions of sighah, conditions of capital and conditions of profit. Conditions of agreement cover first, the sahibul mal and the mudharib have to mention the law regarding the contract clearly. Second, the ijab (offer) and qabul (acceptance) must be mentioned by both parties to represent their agreement to abide to the contract (aqad). 
Conditions of sighah pay attention to these matters. First, the offer and acceptance must clearly show the reason for the contract. Second, the offer and acceptance must be done in the contract signing event. Third, contract is done in writing, either written in the normal methods or by using other communication and modern methods.

Capital in mudharabah is the sum of money or assets which is contributed by the sahibul mal to the mudharib for the purpose of a joint venture. Conditions for capital are also drawn. First, the amount and type of the capital must be known to the parties involved. Second, capital can be in the form of money or valuables. If a capital is in term of asset, then the asset should be valued at the time of signing the contract. Third, the capital cannot be in term of deferred payment and must be paid either as and when it is required or a total lump sum, based on the agreement.

The concept mudharabah can summarised in the following figure. 
INTERNATIONAL JOURNAL OF ACADEMIC RESEARCH IN BUSINESS AND SOCIAL SCIENCES

Vol. 8, No. 10, Oct. 2018, E-ISSN: 2222-6990 @ 2018 HRMARS

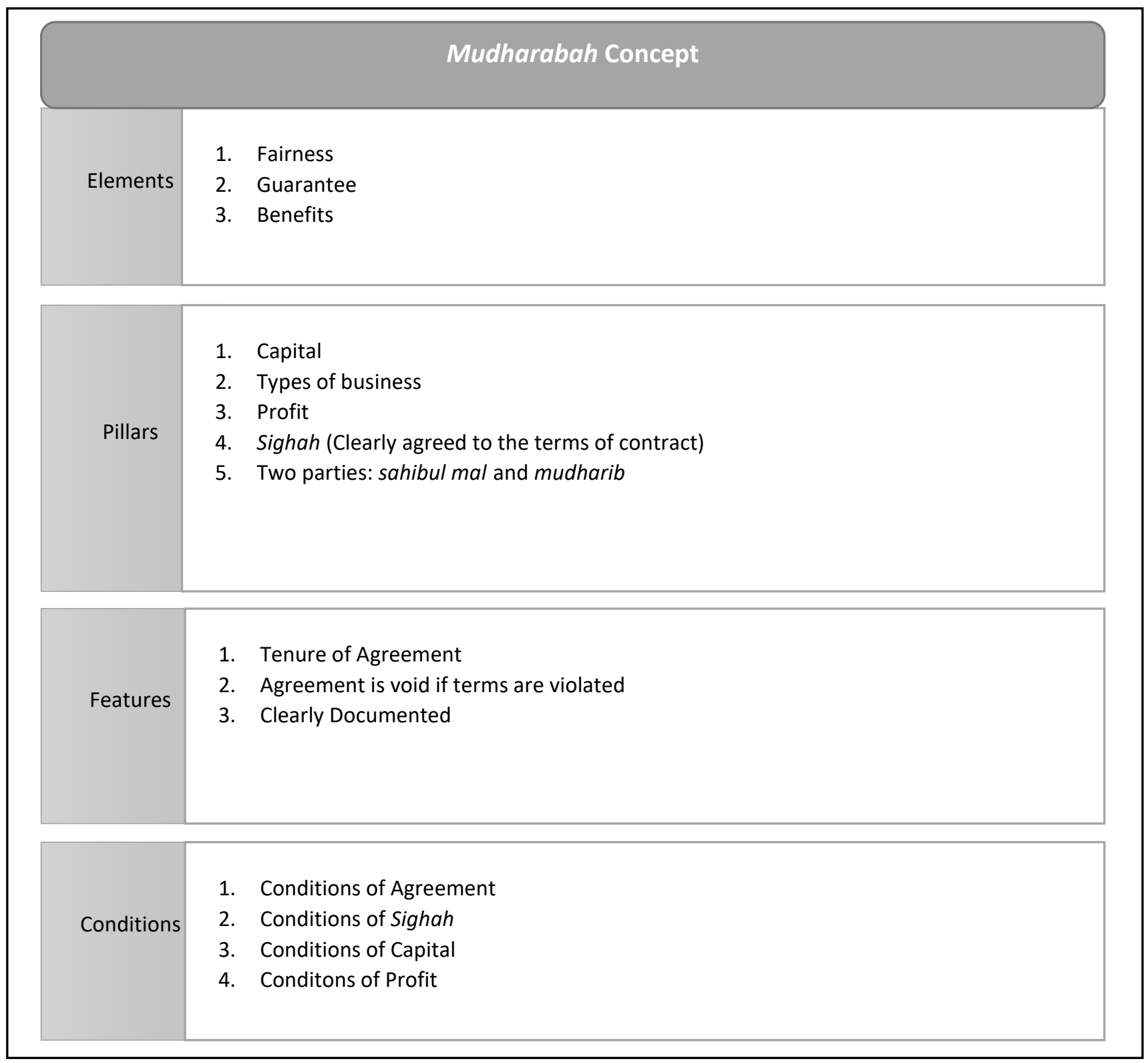

Figure 2. Summary of Mudharabah Concept

Profit in mudharabah is a sum earns as a surplus from the capital invested. The conditions on profit include the following. First, the profit must be shared by both parties, and not of either party only. Second, the profit-sharing ratio must be made known to each party involved and clearly stated in terms of percentage at the start of the agreed contract. Any changes in the profit-sharing ratios must be agreed by both parties. For example, 60\% from profit for the sahibul mal and $40 \%$ for the mudharib. Third, the sahibul mal must bear all the losses from mudharabah venture, and the mudharib should not pay a single cent, unless the losses are because of intentional negligence by the 
INTERNATIONAL JOURNAL OF ACADEMIC RESEARCH IN BUSINESS AND SOCIAL SCIENCES

Vol. 8, No. 10, Oct. 2018, E-ISSN: 2222-6990 @ 2018 HRMARS

mudharib. Therefore, in case of genuine unfavourable economic climate, the mudharib's losses are in term of time and energy spent only.

Smart business management capability is one of the critical success factors of a business venture. As mentioned by Mohd Rosdi (2014) in the context of tahaluf siyasi (political treaty), based in Al-Quran and Hadith, there are three essence in building and shaping smart management capability. First, smart in prioritising the important matters from other things. Second, avoiding clashes among Muslims, and third, smart in formulating and executing strategies. Thus, these traits are advantageous to be possessed by a mudharib in a mudharabah venture to increase the success rate.

\section{Current BNM Guideline}

There are no standards, guideline or at least a framework towards those who intend to practice Mudharabah contract in their daily or commercial transaction. The only reliable guideline of this Mudharabah concept can be found in Draft of Shariah Parameter Reference 3: Mudharabah Contract (SPR3), introduced by Central Bank of Malaysia (BNM) in 2009. The purpose of this Shariah Parameter Reference 3: Mudharabah Contract is to provide reference on the nature and features of the contract to the Islamic financial services industry. This is only a parameter for guideline to distinguish the Mudharabah from other contracts in Islamic financial services. The features outlined in this parameter may serve as general guidance for the application of Mudharabah contract. Any practice by the Islamic Financial Institutions (IFI) which is not specified in the parameter may be conducted as long as it does not contradict the features outlined in the parameter.

In the SPR3, a few main provisions are described. According to this draft guideline, the Mudharabah contract is a form of partnership between one who contributes capital (rabb al-mal/capital provider) and the other who contributes efforts in the form of managerial skills (mudarib/manager). Profit from the outcome of the venture is shared between the capital provider and manager according to mutually agreed profit sharing ratio whilst losses are borne solely by the capital provider, provided such loss is not due to the manager's negligence or violation of specified conditions and hence, they do agree that the legitimacy of the Mudharabah contract is founded on the basis of the Quranic verses, the Sunnah of the Prophet Muhammad (SAW), and the consensus of Muslim Jurists (Ijma').

Article 18 and 19 Under Section 5 of this draft guideline, highlighted on the principle of unilateral termination of contract which allows anyone of the contracting parties to terminate the contract unilaterally with the exception if the manager has commenced the work or when both parties have agreed not to terminate the contract during a specified time.

Article 20 meanwhile, is one of the important clause since it highlights on the principal feature of the Mudharabah contract which will definitely be on capital contribution by one party is the essence of Mudharabah. In addition, article 21 allows the capital contribution both in form of monetary or nonmonetary assets. Article $23 \& 24$ are giving a clear guideline as how to solve a conflict in currency in case a monetary assets of different currencies involve. 
Article 24 however, seems to be a bit questionable as it may give rise to some argument as how to interpret it. The Article claimed that 'Capital in the form of non-monetary assets which may include intangible assets shall be valued based on the valuation determined by a third party which may include authoritative bodies, experts or valuers, or as agreed upon by the contracting parties at the time of conclusion of contract. According to this, the issue of intangible assets shall be valued by a few parties who may have their own judgement and value.

The same goes to Article 25 which gives option to redeem the non-monetary capital at its original value invested should it be possible or otherwise at its residual market value upon termination or expiry of the contract. This option will definitely give rise to some conflict just in case the asset had destroyed of or depreciate in value and etc.

Another rebuttable article ought to be article 29 as it gives right to capital provider to gradually withdraw the capital. This seems to might closely affect the manager just in case the capital provider comes with a mala fide in their transaction and intentionally withdraw the capital without any due reason.

Article 34 and 35 meanwhile, highlight on the principle of guarantorship. Article 35 mentioned that the capital provider may require the manager to arrange for an independent third party performance guarantee. The guarantee shall be executed as a separate contract and be utilised to cover for any loss or depletion of capital in the event of misconduct, negligence, dishonesty, fraud or breach of the terms of the contract by the manager. Here, it might rise an issue on who can be the guarantor? And how honest the guarantor is? And to what extend the liability of the guarantor?

However, all the provoked issues may have some solutions by referring to article 36 and 37 which gives some guidelines on the characteristic of who should be the independent guarantor. However, it again, raise a question when article 38 provides that Mudarib may commingle the Mudharabah capital with other third party Mudharabah capital fund provided that the manager shall observe the agreed terms and conditions of the individual Mudharabah contract. In our opinion, this matter, if not properly managed, may create a havoc on the management of the assets in the mudharabah transaction.

Furthermore, Article 39 again, gives right to Mudarib to inject its own fund into the Mudharabah capital which will transform the initial Mudharabah contract into a Musharakah arrangement. This will be another angle to be carefully looked upon since it really requires an honesty and a good skills in managing the venture.

Section 5.3 of the draft guideline, talks on how to manage the mudharabah venture. As everyone aware, mudharib is the one solely responsible in managing the venture. This is exactly stated in Article 4.1 of the said guideline and on top of that the idea that The manager(s) shall not be liable for any loss of capital unless such loss is due to the manager(s) negligence, dishonesty, misconduct or breach of terms of the contract. This is definitely consistent with the real meaning of mudharabah contract. 
INTERNATIONAL JOURNAL OF ACADEMIC RESEARCH IN BUSINESS AND SOCIAL SCIENCES Vol. 8, No. 10, Oct. 2018, E-ISSN: 2222-6990 ㄷ 2018 HRMARS

But this is the point, of how we people might be afraid and feel unsecured on his interest. But the strong believe and faith in Sunnah of how our prophet Muhammad (PBUH) practiced and led his daily commercial transaction will be the main pillars in believing the best deal behind this mudharabah concept.

For the use of developing the mudharabah contract, the selected provision as summarised in the folowing table may be included to address the issues concerned by the BNM.

Table 1. Summary of Provisions in SPR3 (Source: Bank Negara Malaysia)

\begin{tabular}{|l|l|l|}
\hline No. & Selected Provisions & SPR3 \\
\hline 1 & Concepts and modus operandi of Mudharabah contract & \\
\hline 2 & Capital contribution & Articles 20 and 21 \\
\hline 3 & Unilateral termination of contract & Articles 18 and 19 \\
\hline 4 & Different currencies settlements & Articles 23 and 24 \\
\hline 5 & Intangible assets valuation & Article 24 \\
\hline 6 & Intangible assets redemption & Article 25 \\
\hline 7 & Gradual withdrawal of capital & Article 29 \\
\hline 8 & Guarantorship & Articles 34 and 35 \\
\hline 9 & Independent Guarantor & Articles 36 and 37 \\
\hline 10 & Conversion of Mudharabah into Musyarakah & Article 39 \\
\hline 11 & Role and Responsibility of Mudharib & $\begin{array}{l}\text { Section } 5.3 \\
\text { Article } 4.1\end{array}$ \\
\hline 12 & Scope of Power of Mudharib & Articles 43 and 44 \\
\hline
\end{tabular}

Meanwhile, article 43 and 44 guide us on the powers of the manager which shall be provided under the terms and conditions of the contract which may include the scope and assignment of management of Mudharabah capital to a third party. And article 44 meanwhile, talks on the scope of the restricted Mudharabah contract may specify conditions restricting the manager's role/functions such as determination of location, period for investment, type of project and commingling of funds, provided it does not nullify the purpose/objective of the contract. However, the restrictions shall not unduly constrain the manager.

All the provisions discussed above gives an idea of how the Central Bank of Malaysia, should pay more attention and tried to provide clearer guideline on the implementation of mudharabah contract.

\section{Findings: Elements of Mudharabah (Interview Responses)}

Interviews with eight selected persons are recorded. The informants have different backgrounds related to Mudharabah. They are either academicians, lawyers, Shariah advisors, entrepreneurs or investors. The interviews are based on three Mudharabah elements; justice, guarantee and benefits. Their responses are summarised as follows. 


\section{The Element of Justices}

From justice point of view all informants agreed on this element that mudharabah offers. As both sahibul mal and mudharib risks their own capital and energy respectively, it is preferred for the profit sharing ratio to be at 50:50, but negotiable. As loss of capital will be solely borne by sahibul mal, it is suggested that close monitoring should be in place to reduce the risk of business failure. However, to be just to the mudharib, the sahibul mal should not interfere with the mudharib's business activities. To reciprocate, the mudharib needs to be sensitive with risk exposure taken. In case of hidden profit, the sahibul mal has the right to benefit the profit fully and pay the mudharib his respective fees only. These terms should be contractually predetermined to avoid dispute and dissatisfactions among the parties involved later.

Having said that, the justice element is difficult to be uphold if the party involved is a bank. To be competitive, banks have reserves called profit equalisation reserves (PER) which objective is to smooth up the profit trends and offer profit at market rate. When the profit is higher than the market rate, the sahibul mal will not benefit fully as the extra profit above the market rate will be kept in this reserve account. This is an example of injustice to the sahibul mal. This reserves will be reinvested and the accumulated amount will cause problems to banks as the way on how to manage it can be very complicated and challenging. On another notes, when bank acts as sahibul mal, it is also not cost effective for the banks to monitor mudharib's activities very closely, thus the contract can become very risky. Therefore, it less likely to recommend bank as a counterparty in a mudharabah contract. Instead, mudharabah is more suitable to be contracted among individuals than with banks.

\section{The Element of Guarantees}

To guarantee upright practices, trust is the main thing for Mudharabah among the parties involved in the mudharabah. Guarantee is to ensure that the sahibul mal is only monitoring and not interfering the business activities, while the mudharib is doing the business uprightly with faith and integrity to earn desired profit. The selection criteria on the mudharib and halal business activities are deemed the most vital ones. Only trusted individuals (friends or good track records) should be considered. Burden of Proof (Aku Janji) is necessary to increase the guarantee and reduce risks. Transparent reporting by the mudharib is also required.

In terms of tenure, 6 to 12 months is recommended to reduce risks. Some contracts do not predetermine the contract period but 12 months is common. Capital limit (25\% of total capital) to enter mudharabah is highly recommended. Capital disbursements can be made staggerredly, not as lump sum. The mudharib will write the capital uses when needed, and if justified the sahibul mal will release the disbursement of amount required. This can help to guarantee and monitor the right uses of the capital. Profit ratios need not be 50:50 because it will depend on the type of business and mutual agreements. This profit sharing should be on net profit. 


\section{The Element of Benefits}

Mudharabah contributes benefits in terms of social, economic and religion. Cooperation based on ukhwah can be practiced between parties involved. If many investors involved in one business project, the system will be solid. Teamwork spirit in Islam can be practiced, with trust as the main pillar.

Mudharabah will beautify current venture capital practices. Both investors and Mudharib, when working together is similar to jihad in the battle of economy. Skills possessed by the Mudharib can be utilized to the full extend and will not be wasted due to capital lacking. Funds possessed by the investors are not wasted as it can be invested in a good business.

Another benefit is that mudharabah is alternative to non-halal funding/financing. Muslims economy can be expanded and strengthened more easily and in halal ways.

\section{Proposed Innovative Revived Mudharabah Contract: Framework}

The objective of this research is to propose innovative solutions to revive the mudharbah contract in order to enhance implementability particularly at individual levels among entrepreneur (mudharib) and investor (sahibul mal), as well as improve the substance over form of a mudharabah contract. Based on the findings, the following is the proposed framework in reviving the contract.

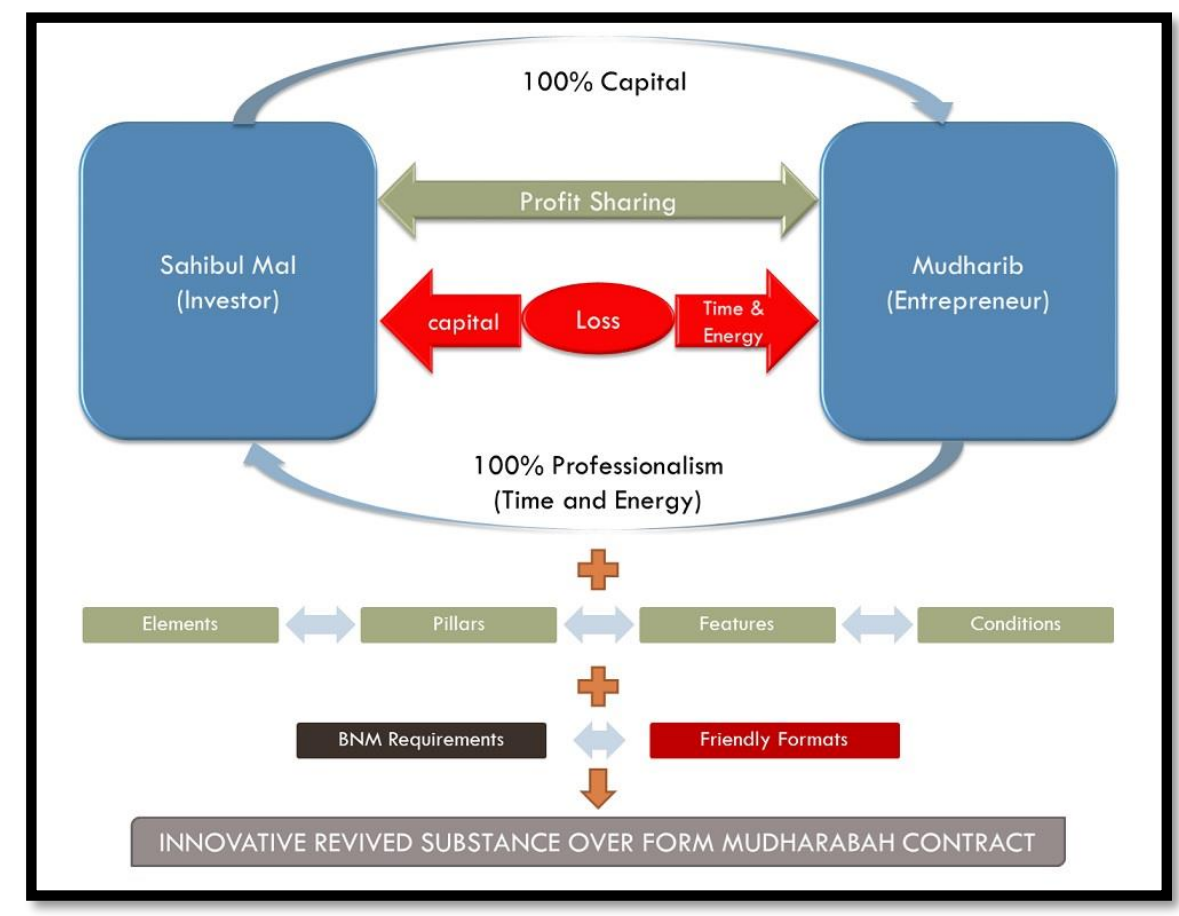

Figure 3. Proposed Framework for Innovative Revived Mudharabah Contract 


\section{Proposed Clauses}

The main aim is to include all the Shariah requirements as well as understandable by parties involved. As opposed to current contract which reflects mudharabah as an embedded product in an engineered instrument, clauses are to include/reflect the followings:

- Mudharabah elements

- Mudharabah features

- Mudharabah pillars

- Mudharabah conditions

- Additional relevant requirements from the BNM guideline

- Preventive measures as described in the informant responses

\section{Proposed Format}

The format should be friendly and understandable at individual levels to enhance substance over form of a Mudharabah contract. The format needs to be clear and concise to investors and entrepreneurs. The language is preferable to be in layman terms, but accepted legally. The proposed format is to include these headings to assist the implementations which are:

- Responsibility and limitations of investors

- Responsibility and limitations of entrepreneurs

\section{Conclusions}

The mudharabah concepts are not known to many including the entrepreneurs who are looking for capital and investors who wish to grow their savings. The current contracts deficiencies have resulted in lower trust in the true potential of the mudharabah, a waste of possible best solution to entrepreneurial ecosystem dilemma. The revived mudharabah contract is timely to realise the potential of mudharabah. Pure mudharabah contract made more friendly, understandable and inclusive of all required Shariah principles and guidelines, has potential contributions as an innovative solutions to the issues.

\section{Acknowledgement}

Huge appreciation to chief editor and anonymous reviewers for helpful comments towards the realisation of this article. This research was supported by the Center for Islamic Development Management Studies (ISDEV), Universiti Sains Malaysia, Pulau Pinang, Malaysia and by MyRA Short Term Research Grant Scheme with team-university, Universiti Sains Malaysia (SGJP MyRA Keserakanan USM 2017).

\section{Corresponding Author}

Dr. Mohd Syakir Mohd Rosdi

Senior Lecturer

Center for Islamic Development Management Studies (ISDEV)

Universiti Sains Malaysia,

Penang, Malaysia.

Email: mohdsyakirmohdrosdi@gmail.com/mohdsyakir@usm.my 
INTERNATIONAL JOURNAL OF ACADEMIC RESEARCH IN BUSINESS AND SOCIAL SCIENCES

Vol. 8, No. 10, Oct. 2018, E-ISSN: 2222-6990 @ 2018 HRMARS

\section{References}

Aliber, M., Kirsten, M., Maharajh, R., Nhlapo-Hlope, J., \& Nkoane, O. (2006). Overcoming underdevelopment in South Africa â€ $€^{\mathrm{TM}} \mathrm{s}$ second economy Overcoming underdevelopment in South Africa's second economy 1. Development Southern Africa, 23(1).

al-Nawawi, I. (2007). Raudhatun Salihin. Jakarta, Indonesia: Pustaka Azzam.

Chhay, D. (2011). Women's economic empowerment through microfinance in Cambodia. Development in Practice, 21(8),https://doi.org/10.1080/09614524.2011.606891

Groot, R.D., Fisher, B., \& Christie, M. (2010). Integrating the ecological and economic dimensions in biodiversity and ecosystem service valuation. The Economics of Ecosystems and Biodiversity: The Ecological and Economic Foundations, (March). https://doi.org/10.1017/s1355770x11000088

Diaz, F. G. I. (2016). Planning and Urban Growth. What to do with Urbanized Vacant Areas in the Land of Valencia? International Journal of Sustainable Development and Planning, 11(6), 930-938. https://doi.org/10.2495/SDP-V11-N6-930-938

Fairbourne, J. S., Gibson, S. W., \& W. Gibb Dyer, J. (Eds.). (2007). Micro Franchising: Creating Wealth at the Bottom of the Pyramid. Micro Franchising Creating Wealth at the Bottom of the Pyramid. Massachusetts: Edward Elgar Publishing Limited.

Kingabdulaziz, U. (2009). Issues in the International Financial Crisis from an Islamic Perspective. (U. KingAbdulaziz, Ed.). Jeddah.

Koveos, P., \& Randhawa, D. (2005). Financial Services For The Poor: Assessing Microfinance Institutions. Managerial Finance.

Kwon, W. J. (2007). Islamic Principle and Takaful Insurance : Re-evaluation. Journal of Insurance Regulation.

Mohd Rosdi, M. S. (2014). Tahaluf siyasi Dalam Ekonomi Politik Islam: Satu Kajian Teoretis. Universiti Sains Malaysia.

Rosdi, M. S. M.\& Mohd Razif, N. A. (2017). Uswah hasanah country of khalifah umar abdul aziz: an islamic political economy research. International Journal of Academic Research in Business and Social Sciences, Vol. 7, No. 6. DOI: 10.6007/IJARBSS/v7-i6/3026. URL: http://dx.doi.org/10.6007/IJARBSS/v7-i6/3026.

Rosdi, M. S.M. \& Mohd Razif, N. A. (2017). Uswah hasanah country of khalifah umar abdul aziz: an islamic political economy research. International Journal of Academic Research in Business and Social Sciences, Vol. 7, No. 6. DOI: 10.6007/IJARBSS/v7-i6/3026. URL: http://dx.doi.org/10.6007/IJARBSS/v7-i6/3026.

Rosdi, M. S.M. (2013). Ekonomi politik Islam: Teori dan falsafah. Kuala Lumpur: Dewan Bahasa dan Pustaka.

Rosdi, M. S.M. (2014a). "Mencari ekonomi holistik: Antara ekonomi Islam dan ekonomi politik Islam”, dlm. Internasional Pembangunan Islam I (KIPI-I). Universitas Jember, Indonesia.

Rosdi, M. S.M. (2014b). Islamic Political Economy: A Special Reference to the Use of Tahaluf Siyasi in the State of Kelantan, Malaysia. American International Journal of Contemporary Research, Vol. 4, No. 5, May 2014.

Rosdi, M. S.M. (2014c). Tahaluf siyasi dalam ekonomi politik Islam: Satu kajian teoretis. Thesis was submitted as a requirement for a PhD, Universiti Sains Malaysia. 
Rosdi, M. S.M. (2015a). Conceptualization of Islamic Political Economy. American International Journal of Social Science, 4 (4).

Mohd Rosdi, M. S. (2015b). Tahaluf Siyasi Dalam Ekonomi Politik Islam. Ekonomika: Jurnal Paradiama Islam Di Bidang Keuangan, Ekonomi dan Pembangunan, 3 (1), 56-82.

Rosdi, M. S.M. (2015c). The Roles of Tahaluf Siyasi in Political Unity. International Journal of Humanities and Social Science, Vol. 5, No. 7, Julai.

Rosdi, M. S.M. (2015d). Ummah Economic Remedy: Between Islamic Economics and Islamic Political Economy. Journal of Business Management \& Economics, [S.I.], 4 (01),. DOI: http://dx.doi.org/10.15520/jbme.2016.vol4.iss01.169.pp38-46.

Sanyal, P., \& Mann, C. L. (2010). The Financial Structure of Startup Firms: The Role of Assets, Information, and Entrepreneur Characteristics. Boston.

Siddiqi, K. (2008). Potential of Islamic Microfinance in Pakistan. Loughborough University.

Stubbs, W. \& Cocklin, C. (2008). Conceptualizing a "Sustainability Business Model." Organization \& Environment, 1(2), 103-127. https://doi.org/10.1177/1086026608318042 